\title{
Investigation of Science Technology Ecocultural Society (STEcS) Model to Enhance Eco Critical Thinking Skills
}

\author{
Wahyuni Purnami $^{(1)}$, Sarwanto Sarwanto ${ }^{(2)}$, Suranto Suranto ${ }^{(3)}$, Retno Dwi Suyanti ${ }^{(4)}$, Mauro \\ Mocerino ${ }^{(5)}$
}

(1) Universitas Katholik St. Paul Ruteng, Indonesia

(2) Universitas Sebelas Maret, Indonesia

(3) Universitas Sebelas Maret, Indonesia

(4) Universitas Negeri Medan, Indonesia

(5) Curtin University, Australia

*Correspondence to: wpurnami@gmail.com

\begin{abstract}
The purpose of this study was to investigate the goodness fit model of Eco Critical Thinking Skills (ECTS) and effectiveness Science Technology Ecocultural Society (STECS) model in elementary school teacher education programs. Participants in this study were 229 students, taken from 3 universities. The data collection method was an open ended essay test and questioner. The research analysis the goodness fit model used was Lisrel 8 and effect size analysis. The results of the investigation indicated that the construct analysis on the instrument model was categorized as a good fit model category with P-value 0.28 (>0.05), RMSEA $0.02(<0.08)$ and other indicators of fit model were above 0.90 . Analysis of the effect size based on Cohen's d criteria of 1.391 ( $>0.08$ ) is classified as very high criteria. This research concluded that instrument is good fit, Interpretation dimension is highest support. STEcS model is effective to enhance Eco Critical Thinking Skills at elementary school teacher education program. The research implication is Eco Critical Thinking Skills of students can be improved through the application of the STECS model. The STECS model is an alternative model for preparing 21st century learning.
\end{abstract}

Keywords: effectiveness; Science Technology Ecocultural Society (STEcS) model; eco critical thinking skills

Article info: Submitted | Revised | Accepted

Recommended citation: Purnami, W., Sarwanto, S., Suranto, S., Suyanti, R. D., \& Mocerino, M. (2021). Investigation of Science Technology Ecocultural Society (STECS) Model to Enhance Eco Critical Thinking Skills. Journal of Innovation in Educational and Cultural Research, 2(2), 77-85.

\section{INTRODUCTION}

Environmental problems occur from the local to the global level requiring indigenous based local wisdom (Hiwasaki et al., 2014). Environmental problems at the local level start from environmental problems at the family level. Environmental problems at the family level include problems with organic waste management and water pollution due to family waste production. Environmental problems are also a global problem. The 139 members of the Intergovernmental Panel on Climate Change (IPCC) regularly discuss environmental issues. One of the efforts to reduce environmental problems is by fostering environmental awareness.

Environmental awareness has a significant relationship with cognitive and affective skills (Turan \& Altuntas, 2018). Critical thinking skills are cognitive skills of students that can be developed by integrating some subjects (Cáceres et al., 2020). Many studies have be done to improve critical thinking skills (Kwan \& Wong, 2015; Wechsler et al., 2018; Wijayanti et al., 2019), however research on ecological (eco) critical thinking skills requires more specialized research in preparing on environmentally conscious generation. There is no previous study which focused at model of learning to enhance eco critical thinking skills. Therefore this study investigated enhancement of STECS model to improve eco critical thinking skills. Critical thinking skills in the environment are very important to be given to students in preparing for 21st century learning that cares about the preservation of nature.

Critical thinking skills on the environment (Eco Critical Thinking Skills) are cognitive skills used to identify, interpretation, inference, explain, analyse, and evaluate materials regarding the environment. Student's critical thinking skills can be improved through continuous practice (Facione, 2011). Therefore, eco 
critical thinking skills in students can be improved through training in environmental education activities to identify problems, interpretation and the other dimensions. Critical thinking skills can be improved with instructional model development (Vong \& Kaewurai, 2017). Cognitive ability related to environmental awareness. Research conducted from 2005 - 2015 in 129 countries concluded that when cognitive abilities increase by one standard deviation, awareness of climate change increases by $19 \%$ (Salahodjaev, 2018). One study states that education about the environment needs to be taught starting at an early age (Choe et al., 2020). Therefore, critical thinking skills need to be taught from early childhood on environmental material. Based in many studies, it is assumed that eco critical thinking skills can be improved through instructional model development that provide continuous training especially material on environmental awareness.

Material on environmental awareness is one of the recommended materials for $21^{\text {st }}$ century learning, $21^{\text {st }}$ century learning requires renewal in various matters in the field of education (Heinrichs, 2016;Teo, 2019). One form of reform in the education sector is to prepare students who can collaborate, communicate, and solve problems (Stadler et al., 2020). Material on environmental awareness needs to be delivered in the right model so that students can collaborate, communicate, be creative, and think critically following the demands of 21st-century learning.

The demands of 21st-century learning and current environmental problems such as climate change, acid rain (Monroe et al., 2017) are important issues to deal with. Therefore, some research studies need to be carried for the sake of environmental awareness covering material, learning models, and even the involved participants from the elementary school level to the university level. In this study, the development of the STECS model was a learning model that has strong concept formation characteristics. As such, students can being construct to their knowledge through problem-based learning experiences. The STECS model also allocate students an opportunity to apply their knowledge to solving problems in society. To obtain accurate model development data, it is necessary to carry out an analysis the effectiveness of the STEcS model in improving critical thinking skills about the environment. Then, the outcome of this study was to measure the goodness fit model and test the effectiveness of the STECS model regarding critical thinking skills in the environment.

The success of measuring a research is determined by the quality of the instrument. A good instrument is able to measure what should be measured. A good instrument is able to bring out the latent ability of students (Sumintono \& Widhiarso, 2015). The effectiveness of the model is a statement or measurement result showing the achievement of the learning model application to achieve the goals of developing the model itself. The learning model effectivity in this study is based on the different effect size of variable between the control and experimental groups, the consideration of students' interest in learning process, and the implementation of the steps in the teaching-learning model (Gibson, 2015). As such, the effect size is a value that shows the magnitude of the difference in variables from various groups. The effect size is a statistical analysis to determine the effectiveness or strength of the model, which generally uses Cohen's criteria and hedge's (Aoki, 2020). The groups that can be used to measure the effect size are the control group and the experimental group as well as the comparison group. The effect size is an analysis that is often used in meta-analysis and popularly used in recent years (Fan \& Konold, 2010; Bowman, 2012). In this study, the effect size used is to compare the mean difference between the experimental group and the control group. Participants in this study were students of prospective elementary school teachers program, with the expectation that they could provide a foundation for environmental concern for their students in the future.

This study analyses the effectiveness of the STECS model which is applied to elementary school teacher education students, especially material on environmental pollution and waste management. The research questions were formulated into 2 research questions, namely: How is the goodness of fit model on the instruments used in research to improve Eco Critical Thinking Skills? How is the effectiveness of the STEcS model applied in the subject of pollution and waste management in Elementary School Teacher Education (PGSD) students?

\section{METHODS}

This research paradigm is quantitative research, by testing the good fit of the model and the effectiveness of the STECS model on environmental pollution and waste management subject matter. The good fit of the model in this study is based on criteria consisting of Chi Square and probabilitas, Root Mean Square Error of Approximation (RMSEA), Normed Fit Index (NFI), Comparative Fit Index (CFI), Goodness of Fit Index (GFI), Adjusted Goodness of Fit Index (AGFI) dan Root Mean Square Residual (RMSR) (Jöreskog \& Sörbom, 1993; Chopra et al., 2019). 


\section{Participants}

Participants in this study consisted of PGSD students from 3 universities, namely universities in Surabaya-East Java, universities in Surakarta-Central Java and universities from Manggarai-Flores, East Nusa Tenggara. This demographic distribution is to get an idea of the effectiveness of the applicable model. used in various demographic location classifications. The first step to determine participants was carried out by collecting data on small cities and big cities and metropolitan cities. Each city will collect data on universities that have a PGSD study program, namely Universitas PGRI-Surabaya, Universitas W.R. Supratman-Surabaya, UNESA-Surabaya, Universitas Sebelas Maret-Surakarta, Universitas Selamet Riyadi-Surakarta, Universitas Muhamadiyah Surakarta, Unika St, Paulus ruteng-Flores, Universitas Flores, STKIP Citra Bakti Bajawa-Flores Nusa Tenggara Timur. The second step, each university that has a PGSD study program is randomly selected based on the city classification. The results of sampling, the research location was carried out at UNESASurabaya, UNS Surakarta dan UNIKA Ruteng, Manggarai-Flores Nusa Tenggara Timur. The number of participants was 229 PGSD students. The number of samples was 73 students from metropolitan cities (Surabaya), 79 students from big cities (Surakarta-Central Java), and as many as 77 students from small cities (Manggarai-Flores, East Nusa Tenggara).

\section{Instrument}

The research instrument used an open-ended essay test and a questionnaire sheet with a linket scale. The assessment rubric follows the SOLO (Structure Observe Learning Outcome) rubric theory. The assessment rubric is: score 1 (the answer does not match the question, students cannot respond to the question well, the information provided is very simple and does not match the question); score 2 (the answers given are correct according to scientific, students can respond the questions but the responses cannot be understood and only provide one part of the idea); score 3 (correct answers according to scientific, students can provide several parts of the idea but not yet interconnected and comprehensive); score 4 (correct answer according to scientific, students can provide several parts of the idea and are related); score 5 (correct answers according to scientific, students can provide several parts of ideas that are interconnected and relate to facts in the environment and can generalize from existing concepts to concepts that are outside, which shows students mastering the material).

\section{Data collection}

Data collection was carried out by conducting a test of eco critical thinking skills which consists of the dimensions of problem identification, interpretation, analysis, inference, explanation, and evaluation (selfregulation). The open answer essay test was conducted in the experimental class and the control class at three universities. Data collection to determine students' interest and comfort in learning using the STEcS model was carried out using a questionnaire. The questionnaire is given with anonymously, in Indonesian, so that respondent can fill out the questionnaire more objectively without any pressure, and the information is more accurate. Students have been given information on the importance and benefits of filling out the questionnaire, this is to maintain the seriousness of students in filling out the questionnaire.

\section{Analyzing of Data}

The fit model used to improve Eco Critical Thinking Skills was analyzed using Lisrel 8. The effectiveness of the STECS model in learning pollution and waste management subjects is analyzed with the R-Stat to determine the effect size according to Cohen's d criteria. Quantitative descriptive analysis to describe the feasibility of the STECS model as well as student interest and comfort in participating in learning using the STECS model. The category used to measure the results of the effect size is used, as the standard criteria using cohen's criteria d. Standard effect size criteria are based on Cohen's criteria d that shown in Table 1.

Table 1. Effect Size Standard Criteria

\begin{tabular}{ccc}
\hline & Score Standard & Criteria \\
\hline Cohen's d & $0,2-0,4$ & low \\
& $0,5-0,7$ & medium \\
& $0,8-1,2$ & high \\
& $1,3<\mathrm{X}$ & Very high \\
\hline
\end{tabular}

The cohen's $d$ indicator is

$$
. d=M 1-M 2 / S
$$

$M 1-M 2$ is the difference between the group means 
$\mathrm{S}$ is the standard deviation either group

\section{RESULT AND DISCUSSION}

The results of the Goodness fit model analysis show that RMSEA $0.02(<0.08)$ has met the standards according to the specified criteria, the P-value is 0.28 ( $>0.05)$. All other indicators (AGFI, GFI, IFI, NFI, CFI, and TLI) results above 0.90 which shows the model can be acceptable. The Goodness of fit model is presented in Table 2.

Table 2. Goodness of Fit Model STEcS

\begin{tabular}{|c|c|c|c|}
\hline Index & Standard Value & Value & Explanation \\
\hline Chi Square and Probability & $P>0.05$ & 0.24 & Good Fit \\
\hline Root Mean Square Error of Approximation (RMSEA) & $\leq 0.08$ & 0.02 & Good Fit \\
\hline Normed Fit Index (NFI) & $\geq 0.90$ & 0.90 & Good Fit \\
\hline Comparative Fit Index (CFI) & 0.90 & 0.99 & Good Fit \\
\hline Goodness of Fit Index (GFI) & $\geq 0.90$ & 0.96 & Good Fit \\
\hline Adjusted Goodness of Fit Index (AGFI) & $\geq 0.90$ & 0.94 & Good Fit \\
\hline Root Mean Square Residual & $\leq 0.10$ & 0.04 & Good Fit \\
\hline
\end{tabular}

The Comparative Fit Index (CFI) shows a value that is close to the maximum because it is close to a value of 1.0, this indicates an incremental fit, with a good index. CFI is the recommended index because it is not influenced by sample size. This has fulfilled the goodness of fit model, with the T-Value of each component above $>1.96$. Dimensions of identification, interpretation, explanation, inference, analysis, and evaluation (self-regulation) have contributed and are related to strong ties. The loading factor value shows the value of the contribution of each aspect of critical thinking skills as shown in Figure 1.

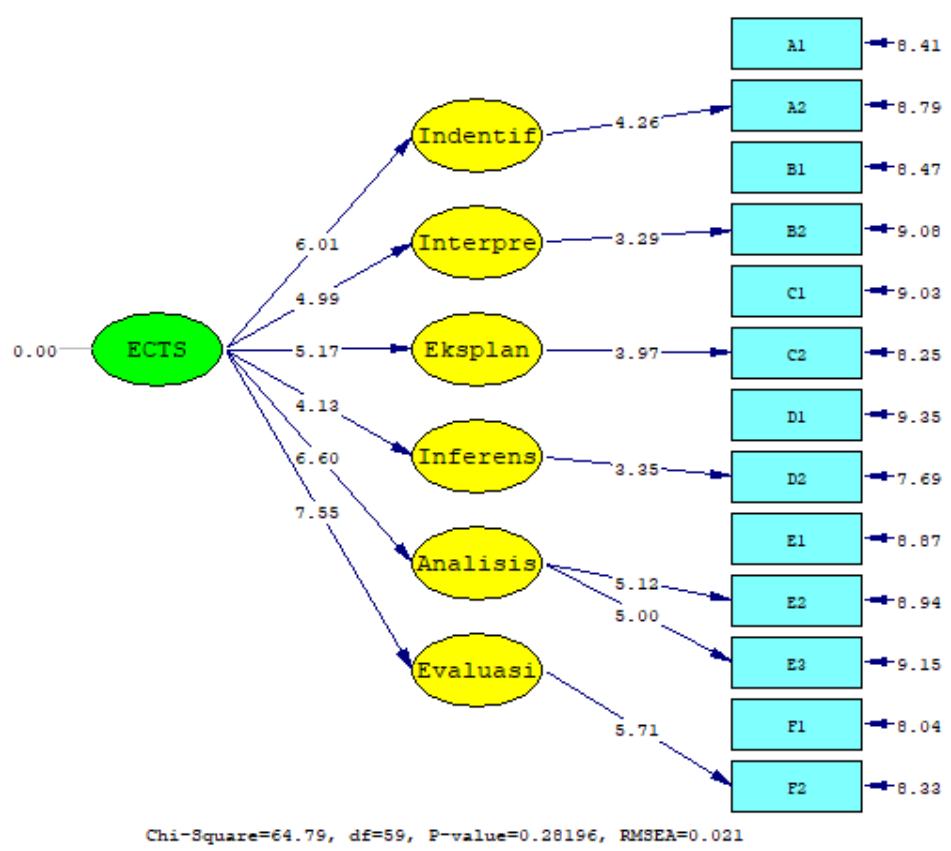

Figure 1. T-value of Eco Critical Thinking Skills (ECTS)

Each dimension has a high value of support for eco critical thinking skills in the application of a STEcS model. The standard value to be able to support a minimum of 0.70 in each dimension. An illustration of the standard support pattern in each dimension is presented in Figure 2. 


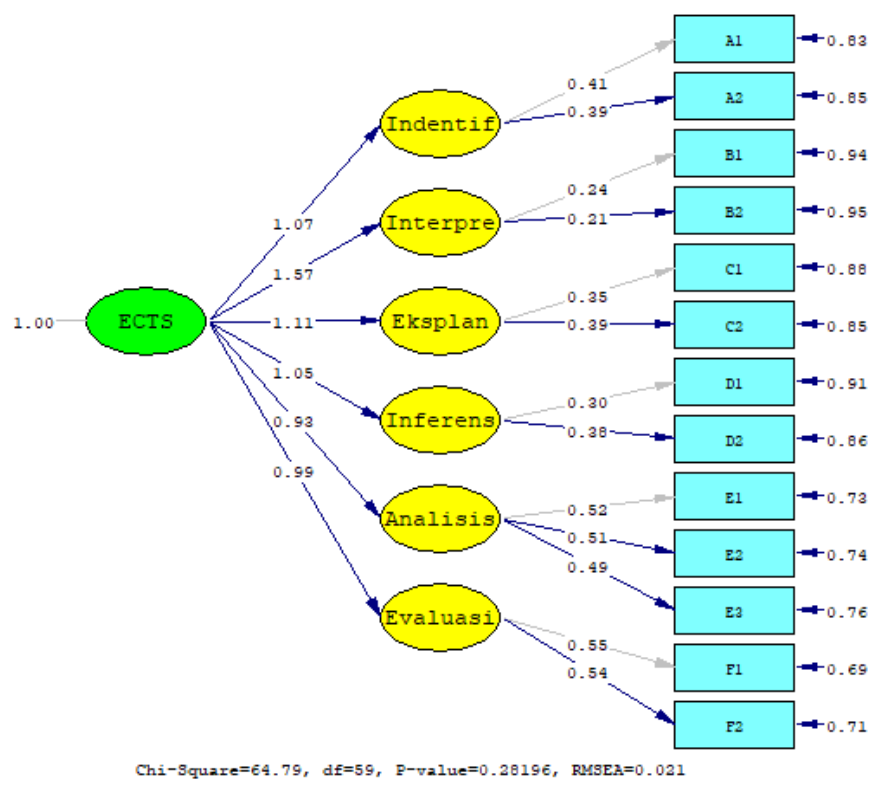

Figure 2. Path Diagram Standardized Support dimension

The contribution of each aspect has met standard value so that all aspects can be measured the critical thinking skills, linkages between unidimensional indicators on the instrument, as well as standard relationships between aspects of identification, interpretation, explanation, inference, analysis, and evaluation showing that the aspects used are capable of support critical thinking skills (ECTS).

The effectiveness model can be measured by variables effect size (Borg \& Gall, 2003), the user interested (Chopra et al., 2019), and the syntactic model's implementation. Based on the instrument analysis' result that have met the measurement standards, the effectiveness of the STECS model in learning material pollution and waste management materials, especially for elementary school teacher candidates, the effect size was measured. The effectiveness of the model is based on the effect size value of the comparison between the two groups, namely the experimental group and the control group.

Table 3. The results of the R-Stat analysis showed that the effect size of such comparison

\begin{tabular}{|c|c|c|c|c|c|c|c|c|c|}
\hline \multirow[t]{2}{*}{ Comparison } & \multicolumn{3}{|c|}{ Experiment Group } & \multicolumn{3}{|c|}{ Control Group } & \multirow[t]{2}{*}{ Cohen's d } & \multirow[t]{2}{*}{ Hedges's } & \multirow[t]{2}{*}{ Glass's d } \\
\hline & Mean & Sd & N1 & Mean & Sd & N1 & & & \\
\hline Comparison 1 & 46,41 & 5 & 41 & 39,31 & 5 & 38 & 1,391 & 1,391 & 1,394 \\
\hline Comparison 2 & 29,53 & 2 & 39 & 26,94 & 2 & 38 & 1,289 & 1,285 & 1,200 \\
\hline Comparison 3 & 48,30 & 3 & 42 & 42,62 & 6 & 31 & 1,317 & 1,317 & 1,011 \\
\hline
\end{tabular}

The difference between the control group and the experimental group on the effect size measurement has a high effect on learning using this model. The STEcS model emphasizes the learning process by emphasizing strong concept formation through orientation as well as organizational \& investigative syntax. In the STECS model syntax, students constructed their knowledge based on learning experiences obtained from the results of investigating problems in the field. Apart from forming a strong concept, the STEcS model syntax was able to apply student knowledge in solving problems in society. As such, this helps students to have a direct learning experience. This is why the experimental group and the control group have different effect sizes obtained by high criteria ( $>0.8$ ) in Cohen's d criteria.

The data that supports the effectiveness of the STEcS model in learning is also based on PGSD students' interest in learning process participation which the model was used. The results showing students' interest in the learning process using the STEcS model were obtained from the results of self-evaluation collected from an online questionnaire without mentioning names for the sake of more accurate data results. The results of students' interest and comfort in following the learning process are presented in Figure 4. 


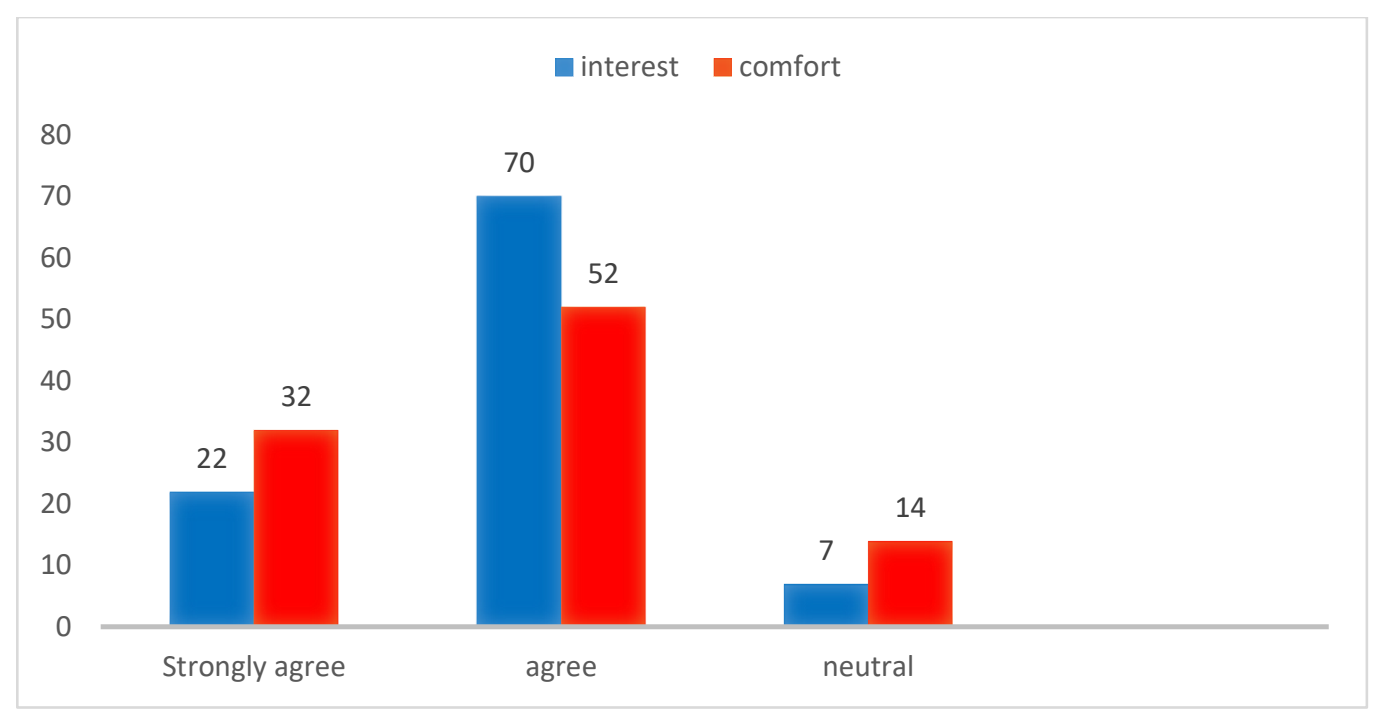

Figure 3. Graph of Interest and Comfort Following the Learning Process

The results of the questionnaire given to students showed that students had a high interest in the learning process implementation using the STECS model. High students' interest occurred as the learning process utilizing the STECS model was carried out comfortably. The students learned both inside and outside the classroom. Students conducted discussions in class flexibly. The application of the model also required means of infrastructure that are easily available in the vicinity and were up to date in nature. This was also another factor making the students' high interest in the learning process.

The Science Technology Ecocultural Society model is a model developed to equip prospective elementary school teacher student candidates to improve critical thinking skills in environmental sustainability. The development of the STECS model consists of 5 syntaxes, namely orientation, organization \& investigation, application, conceptualization, and evaluation. The development of the this model is adapted to the characteristics of the subject of environmental pollution and waste management. Therefore, the development of this model following the characteristics of the subject could provide a basis for prospective elementary school teachers candidates to have the ability to think critically about environmental sustainability. The development of the STECS learning model needs to be carried out by various testing models, including testing the model effectiveness in learning. The effectiveness of the model in learning is an important thing to measure, the effectiveness of the model in learning which can be determined through the learning process carried out from observation (Wiens et al., 2020) and evaluation of learning outcomes by comparing two groups, namely experiment, and control as well as pre-test and post-test (Borg \& Gall, 2003). Therefore, the learning model effectiveness is based on the results of observations of the learning process and the results of self-evaluation and evaluation of learning as measured by various statistical analyzes.

Testing the significance of the classical statistical hypothesis is often used in educational research, especially in research related to biology, including subjects on environmental pollution and waste management. This statistical approach has many drawbacks. Some of the weaknesses in the statistical approach to testing the significance of the null hypothesis include not providing important information about the accuracy of the influence and interaction effects on respondents (Aoki, 2020). Measurement of the Pvalue only provides information that there is an influence but cannot provide how much influence the treatment gives, therefore the measurement of effectiveness needs to show the effect size magnitude (Sullivan \& Feinn, 2012).

The results of the size's effect that have been carried out in this study indicated that the control group and the experimental group have differences in the mean which belongs to the high category. The experimental group, namely the group that was given learning treatment with the STEcS model had a significant difference in mean. The difference between the control and experimental groups achieved an effect size of 1.3 on Cohens'd criteria. This shows that the application of the STEcS model had a high effect on improving environmental critical thinking skills (Eco Critical Thinking Skills).

Factors supporting the improvement of environmental critical thinking skills consist of external factors and internal factors. External factors that impact the success of learning outcomes are also influenced by the emotional condition and situation and the character of the teacher (Braun et al., 2020). The success of learning that influenced by internal factor shows outcomes in the form of interest, learning comfort, namely a positive attitude towards a subject (Demirci, 2017). The ease of learning science provides a deeper learning 
experience for students (Chu et al., 2017). Therefore, external factors in the form of teacher emotional situations, pleasant learning situations are situations that are formed in the application of the STEcS model to improve critical eco-thinking skills.

The application of STECS model is based on contextual problems. Problem-based learning in the surrounding / contextual environment has fostered a sense of interest and a positive response to students towards the learning process. In applying to this model, the knowledge of the students used to solve problems. The application of the model to the experimental class shows that more than 70 percent of students express interest and comfort in the process of learning. Students are interested in learning with the STECS model because this model is based on contextual problems, and students are able to solve the problems by their knowledge. The STECS model application involves students to form concepts through learning experiences from problems in the environment, this is in accordance with research conducted using an eco-garden to encourage sustainable learning (Cheang et al., 2017).

The application of the STECS model goes along with the characteristics of pollution material and waste management. Pollution and waste management materials are parts of the subject of basic science concepts that have the characteristics of processes, products, scientific attitudes, and applications. This suits the characteristics of this model which forms concepts through the learning experience process so that it can construct its knowledge. The characteristics of the model in constructing knowledge itself mirror the research study stating that the activity of constructing knowledge itself is effective learning in science (Kizkapan \& Bektas, 2017). The characteristics of this model also emphasized the stages of its application, so that the knowledge gained by students can be applied to the benefit of society. This is following research stating that the knowledge formed by students is significant with the attitudes that are formed even though only at the average level (Choe et al., 2020)

The stages of implementing the STECS model in pollution and waste management subjects are also carried out indoors and outdoors. As such this is helpful to foster interest and comfort in learning because learning situations and social systems are formed into fun learning. This confirms with a previous research study that states that indoor and outdoor learning activities built learning experiences in students directly (Shume \& Blatt, 2019). Direct experience that is carried out in the application of this model makes students being able to identify problems and implement waste oil management into wax which has higher aesthetic value and usefulness. Direct experience activities through creative things carried out in learning with the STECS model mirrors the previous research study which states that creative students have a positive response to a learning environment that improves learning outcomes (Gucyeter \& Camci, 2020). The characteristics of the model and its application that support the effectiveness of the STECS model in learning pollution and waste management subjects can reach the high category.

\section{CONCLUSION}

The STECS model has been tested on prospective elementary school teacher student candidates with the results of the good fit model and has an effectivity value that is in the high category according to Cohen's criteria. The Interpretation dimension is the highest dimension in supporting Eco Critical Thinking Skills in the application of this model. Students of prospective elementary school teacher candidates expressed their interest and comfort in following the learning process with this model. In this regard, all STEcS model syntax can be implemented in model testing. The STECS model can be a solution to be applied in preparing a generation who has concern and awareness of the environment. Further research can be tested on the application of the STECS model to students at the primary and secondary school levels.

\section{REFERENCES}

Aoki, S. (2020). Effect sizes of the differences between means without assuming variance equality and between a mean and a constant. Heliyon, 6(1), e03306.

Borg, W., \& Gall, M. (2003). Educational Research: An Introduction (A. Burvikovs (ed.); seventh). Pearson Education Inc.

Bowman, N. A. (2012). Effect Sizes and Statistical Methods for Meta-Analysis in Higher Education. Research in Higher Education, 53(3), 375-382. 
Braun, S. S., Schonert-Reichl, K. A., \& Roeser, R. W. (2020). Effects of teachers' emotion regulation, burnout, and life satisfaction on student well-being. Journal of Applied Developmental Psychology, 69(May), 101151.

Cáceres, M., Nussbaum, M., \& Ortiz, J. (2020). Integrating critical thinking into the classroom: a teacher's perspective. Thinking Skills and Creativity, 100674.

Cheang, C. C., So, W.-M. W., Zhan, Y., \& Tsoi, K. H. (2017). Education for sustainability using a campus ecogarden as a learning environment. International Journal of Sustainability in Higher Education, 18(2), 242-262.

Choe, J. H., Kim, C. H., \& Ri, G. H. (2020). An investigation on the environmental knowledge and attitudes of senior middle school students in the Democratic People's Republic of Korea. International Research in Geographical and Environmental Education, 29(2), 146-162.

Chopra, G., Madan, P., Jaisingh, P., \& Bhaskar, P. (2019). Effectiveness of e-learning portal from students' perspective: A structural equation model (SEM) approach. Interactive Technology and Smart Education, 16(2), 94-116.

Chu, S. L., Angello, G., Saenz, M., \& Quek, F. (2017). Fun in Making: Understanding the experience of fun and learning through curriculum-based Making in the elementary school classroom. Entertainment Computing, 18, 31-40.

Demirci, C. (2017). The effect of active learning approach on attitudes of 7 th grade students. International Journal of Instruction, 10(4), 129-144.

Facione, P. A. (2011). Critical thinking: What it is and why it counts. Insight assessment, 1(1), 1-23.

Fan, X., \& Konold, T. R. (2010). Statistical significance versus effect size. International Encyclopedia of Education, 2004, 444-450.

Gibson, D. B. (2015). Revised title: Effect size as the essential statistic in developing methods for mTBI diagnosis. Frontiers in Neurology, 6(May).

Gucyeter, S., \& Camci, E. S. (2020). Creative children in a robust learning environment: Perceptions of special education teacher candidates. Thinking Skills and Creativity, 37, 100675.

Heinrichs, C. R. (2016). Exploring the Influence of 21st Century Skills in a Dual Language Program: A Case Study. International Journal of Teacher Leadership Heinrichs - Exploring the Influence, 37(1), 37-56.

Hiwasaki, L., Luna, E., Syamsidik, \& Shaw, R. (2014). Process for integrating local and indigenous knowledge with science for hydro-meteorological disaster risk reduction and climate change adaptation in coastal and small island communities. International Journal of Disaster Risk Reduction, $10,15-27$.

Jöreskog, K. G., \& Sörbom, D. (1993). Structural Equation Modeling with the Simplis Command Language. Scientific software international.

Kizkapan, O., \& Bektas, O. (2017). The effect of project based learning on seventh grade students' academic achievement. International Journal of Instruction, 10(1), 37-54.

Kwan, Y. W., \& Wong, A. F. L. (2015). Effects of the constructivist learning environment on students' critical thinking ability: Cognitive and motivational variables as mediators. International Journal of Educational Research, 70, 68-79.

Monroe, M. C., Plate, R. R., Oxarart, A., Bowers, A., \& Chaves, W. A. (2017). Identifying effective climate change education strategies: a systematic review of the research. Environmental Education Research, 4622(August), 1-22.

Salahodjaev, R. (2018). Is there a link between cognitive abilities and environmental awareness ? Crossnational evidence. Environmental Research, 166(March), 86-90.

Shume, T. J., \& Blatt, E. (2019). A sociocultural investigation of pre-service teachers' outdoor experiences and perceived obstacles to outdoor learning. Environmental Education Research, 25(9), 1347-1367.

Stadler, M., Shubeck, K. T., Greiff, S., \& Graesser, A. C. (2020). Some critical reflections on the special issue: Collaboration in the 21st century: The theory, assessment, and teaching of collaborative problem solving. Computers in Human Behavior, 104. 
Sullivan, G. M., \& Feinn, R. (2012). Using Effect Size-or Why the P Value Is Not Enough . Journal of Graduate Medical Education, 4(3), 279-282.

Sumintono, B., \& Widhiarso, W. (2015). Aplikasi pemodelan rasch pada assessment pendidikan (pertama). Trim komunikata.

Teo, P. (2019). Teaching for the 21st century: A case for dialogic pedagogy. Learning, Culture and Social Interaction, 21(March), 170-178.

Turan, S. L., \& Altuntas, E. C. (2018). Awareness of secondary school students about renewable energy. 116(116), 741-748.

Vong, S. A., \& Kaewurai, W. (2017). Instructional model development to enhance critical thinking and critical thinking teaching ability of trainee students at regional teaching training center in Takeo province, Cambodia. Kasetsart Journal of Social Sciences, 38(1), 88-95.

Wechsler, S. M., Saiz, C., Rivas, S. F., Vendramini, C. M. M., Almeida, L. S., Mundim, M. C., \& Franco, A. (2018). Creative and critical thinking: Independent or overlapping components? Thinking Skills and Creativity, 27(December 2017), 114-122.

Wiens, P. D., LoCasale-Crouch, J., Cash, A. H., \& Romo Escudero, F. (2021). Preservice Teachers' Skills to Identify Effective Teaching Interactions: Does It Relate to Their Ability to Implement Them?. Journal of Teacher Education, 72(2), 180-194.

Wijayanti, M. D., Rahardjo, S. B., Saputro, S., \& Mulyani, S. (2019). Item analysis of critical thinking skills instrument to measure effectiveness of scientific group inquiry learning (SGIL) model. Jurnal Pendidikan IPA Indonesia, 8(4), 538-546. 